\title{
Exploring Effects of the Educational Investments and Returns on Teachers with Upgraded Qualifications Acquired On Self-Sponsorship in Lusaka District
}

\author{
Chifuwe Avien, Francis Simui and Gistered Muleya \\ University of Zambia
}

\begin{abstract}
An educational investment is the act of spending money on an educational programme with the goal of earning capital appreciation towards future returns. The aim of making an educational investment is that the investment will provide a stream of benefits in future for a profit. The purpose of this study was to explore the effects of the educational investments and returns on the lives of the teachers with upgraded qualifications on self-sponsorship in Lusaka district. Data was generated from ten purposively sampled teachers who upgraded qualifications on self-sponsorship using in-depth interviews, and observations. Findings from the study revealed among others; adequate responses to prompt changes, natural aptitudes and inventiveness, better health, high income employment opportunities and reasonated knowledge. The study concluded that educational investments made on self-sponsorship by teachers accrued benefits of education or returns and the benefits accrued had positive effects on the lives of the teachers who made the investment. Thus it is recommended that teachers who fail to find sponsorship opportunities from the government can still upgrade their qualifications on self-sponsorship because the benefits of education accrued from their educational investments have positive effects on their lives. Additionally, teachers need to improve their knowledge reservoir by upgrading their qualifications in order to keep abreast with the world's advancements in technology. Furthermore, upgrading of qualifications enhances efficiency and effectiveness in the teaching profession.
\end{abstract}

Key words: Educational investment, Upgrading, Benefits of Education, Self-sponsorship, Accrue

\section{INTRODUCTION}

$\mathrm{T}$ his paper is an excerpt from the lead researcher's Master of Education and Development dissertation on Exploring Effects of the Educational Investments and Returns on lives of teachers with upgraded qualifications on self-sponsorship with the focus of public secondary schools in Lusaka district. The Masters programme was offered by The University of Zambia's Department of Educational Planning and Policy Studies.

\section{Context}

Education is recognized as a key factor that determines the social and economic growth of individuals and the society. Education is acquired by investing in it. Investing in education can either be done on sponsorship basis or on selfsponsorship. An investment in higher education is a very important investment for everyone, teachers inclusive, because it offers its beneficiaries several advantages on short and long term. Teachers invest in education through upgrade programmes, either on government sponsorship or selfsponsorship. Teachers who upgrade on government sponsorships are placed in a book tracking system. A book tracking system provides strong commitment by government to offer sponsorships to teachers as well as providing follow up opportunities for them when they are done with upgrading their qualifications (Phiri, 2015). This is not the same situation with teachers who upgrade on self-sponsorship. Teachers who upgraded their qualifications on self-sponsorship had to put efforts and sacrifice their money because of the expected streams of returns that come with obtaining higher qualifications.

The accruing of educational benefits by teachers who upgraded their qualifications on self-sponsorship is expected to bear significant effects on the lives of the teachers who go out of their way to sponsor themselves for further studies. The current state of affairs has seen so many teachers enrolling in higher institutions of learning to upgrade their qualifications on self-sponsorship since the government through the MoGE does not have adequate budgetary provision to sponsor all its teachers for higher qualifications (ZNUT, 2017). One would also argue that the high rate of teachers wanting to upgrade their qualification could also be triggered by some level of awareness arising from their exposure to some civic education knowledge and dispositions. Muleya (2017a; 2017b; 2018a; 2018b; 2018c; 2019); Bergersen \& Muleya (2019); Machila et al (2018); Magasu, Muleya \& Mweemba (2020); Mupeta \& Muleya (2019); Habanyati et al (2020); Mupeta et al (2020) attests to this fact that Civic Education supports experiences, reflections, assumptions that help citizens in gaining great understanding on civic issues and actions. Upgrading of teachers is one such civic issue that resonates with Civic Education awareness and hence taking such an action aimed at improving their welfare as teachers in the larger community. Though the government has not come out clearly to state why it has tremendously reduced the number of teachers it is sponsoring for further studies, it can certainly be concluded that it is riding on the principle, 'who benefits must pay pleas for the private financing of higher studies' (Daniela \& Daniela, 2015). Teachers are aware of the streams of benefits 
that come with the upgrading of their qualifications (BETUZ, 2016). When teachers upgrade their qualifications, the outcome is that they become better educated. Better educated teachers tend to bring about better outcomes on themselves and their students (Kristin \& Erica, 2018). In as much as the upgrading of the teachers' qualifications benefits the teaching profession in the country, teachers who upgraded their qualifications on self-sponsorship also accrue benefits for themselves and these benefits of education have effects on their lives. Teachers who upgraded on self-sponsorship made an investment in education and this investment yielded or accrued returns. The returns accrued have effects on the lives of the teachers, who made the investment. It is not known what the effects are on the lives of the teachers who made the investment and this prompted the researchers to undertake a study and examine the kinds of effects.

\section{Statement of the Problem}

The upgrading of qualifications by teachers in the MoGE has currently seen so many teachers upgrading their qualifications on self-sponsorship because government has stopped providing upgrading opportunities to teachers in large numbers. Upgrading of qualifications on self-sponsorship is an educational investment. The knowledge and skills acquired from this educational investment are important to individual teachers as they can help them respond to current and future potential crises that come with the worlds advancements. So many teachers in Lusaka district have upgraded and continue to upgrade on self-sponsorship because the upgrading of qualifications is a profitable educational investment that yields returns which have positive effects on the investor. It is not clear what the effects are and how they are affecting the lives of the investor.

\section{Purpose of Study}

The purpose of the study was to explore the effects that the benefits of education accrued by teachers who upgraded on self-sponsorship have on their lives.

\section{Specific Objectives}

1. To explore the effects arising from the benefits of education accrued by teachers who upgraded on selfsponsorship.

2. To describe the effects of the benefits of education on the lives of the teachers who upgraded on selfsponsorship.

\section{THEORETICAL FRAMEWORK.}

The theoretical framework applied was anchored on the human capital theory in order to understand the effects of the educational investment and returns, accrued by teachers who upgraded qualifications on self-sponsorship, in their lives. An investment in education brings out the capacity in the investor to work and adapt to new life because education instills in the individuals the correct approach towards life (Winters, 2013). To invest in education means to equip oneself with knowledge and skills needed for personal, national and global development. The human capital theory suggests that education has an integral part and is the driver of the betterment of the human condition (Woessman, 2014). This is because education is a production factor which helps individuals acquires knowledge and skills needed to improve productivity, prosperity and enriching life experiences. The more education one acquires, the more one improves in productivity, prosperity and life experiences. The improvement in productivity, prosperity and life experiences are referred to as benefits or returns to the educational investment. In other words, the benefits or returns to the educational investment bring about human development.

Human development enlarges human capabilities to promote investment in the development of people through skills, work productivity and creativity (Garba, 2016). In this context, education is an investment that equips individuals with knowledge and skills to improve their employability and productive capacities, thereby leading to positive effects in the lives of the individuals. In other words, human capital provides the ability and efficiency of people to positively transform their lives economically and socially using the skills and knowledge learnt from the educational system. There is a positive and strong correlation between educated individuals and the kind of life they lead after being educated. The educated individuals made that investment in education in order to acquire benefits that improve productivity and development in their lives. Improving educational qualifications is a capital good which relates to the concept of human capital and emphasizes that the development of skills is an important factor needed for the attainment of a new life style (Cohen \& Soto, 2015). This means that upgrading of qualifications is associated with a wide range of positive outcomes in the life of a person who has upgraded.

\section{Review of Related Literature}

It is widely accepted that the objective and goal of education is to promote learning and help individuals' master knowledge and develop skills which consequently help them to find better jobs, earn more income and have a higher quality of living. According to the human capital theory, the skills and knowledge accrued from an educational investment are viewed as the enablers of productivity, which form and compensate individuals through wages (United Nations, 2018). Individuals invest in education and training because they believe that the direct costs and opportunity incurred during the education process would be sufficiently compensated. The human capital theory postulates that individuals who bear the costs such as paid school fees and opportunity costs in an educational investment expect that this investment will create a future stream of benefits (Jostein, 2015).

The different levels of investment in education and training, which individuals make, can be explained in their expected returns from the investment. When individuals invest in 
education, they start out low and this makes them desire to make more investments in education and also sacrifice to forgo earnings as they invest. This is because they expect to benefit from the further investments made, which in turn also sufficiently compensates the forgone earnings. The human capital theory predicts that increases in the overall levels of education can benefit individuals and society in ways that are not fully reflected in the returns (Jenkins, 2018).

Earlier studies were conducted by Woessman (2014) to find out the demand for education and qualifications in developing countries. The study investigated why individuals and society as a whole, in the third world countries had started placing education as a priority in their agendas and budgets. The study was a mixed method and was conducted in Kenya and Malawi. The findings of the study established that the demand for education was on the rise in third world countries because education delivers a variety of benefits at many levels. The variety of benefits delivered included benefits for individuals and benefits for society as a whole. However, the study conducted did not address the effects of the benefits of education accrued, on the individuals and society, which the study under review endeavored to address.

Another study was conducted by Wilson (2012) to investigate, why an investment in education is a worthwhile investment. The study was conducted by examining the current and future value of costs and benefits arising from an educational investment. The study was qualitative and findings established from the study revealed that education is one tool that transmits knowledge and skills that facilitate for a new way of looking at life. The findings went on to reveal that education was a worthwhile investment because it inspires innovations, which are essential for individuals and societal development. The gap identified in this study with the study under review was that, the study reviewed earlier on did not address the effects the innovations caused on the lives of the teachers

\section{METHODOLOGY}

A qualitative research methodology approach was used to guide the study. A qualitative research methodology is conducted in a natural setting and involves generating data about human groups in social settings (Slevitch, 2011). Qualitative methods are useful for describing person's lives, lived experiences, behaviors, emotions and feelings, as well as cultural phenomena. With the use of qualitative methods, the researcher described in rich detail phenomena that were investigated from the participants' viewpoints. In this case, the researcher identified the contextual and setting factors, which were related to the phenomena of interest.

\section{Research Design}

Neumann (2007) stated that research designs are a set of instructions to the researcher to gather and analyse data in such a way as to control whom and what to study. The research design used in the study was the descriptive design to obtain pertinent and precise information concerning the current status of a problem or issue and where possible draw valid general conclusion from the facts available (Mason, 2007). The descriptive research design was appropriate for this research because it allowed the research to be conducted in the respondents natural environment, which ensured that high quality and honest data was collected.

\section{Sample Size and Selection Criteria}

Ten (10) participants were purposively sampled for this study because they were teachers who upgraded qualifications on self-sponsorship. The teachers had the knowledge, opinions and experiences on the topic of discussion. The pseudonyms given to the participants were as follows: T1-2020, T2-2020, T3-2020, T4-2020, T5-2020, T6-2020, T7-2020, T8-2020, T9-2020 and T10-2020. In addition, the name of the school where the participants were drawn from, a pseudonym KS1 was assigned to hide their identities. Lusaka central zone was purposively sampled because it houses big grade one secondary schools, with over 100 teachers per school and has got both morning and afternoon pupils, meaning the schools have sessions from morning till evening.

\section{Research Tools}

Data in this study was collected using in-depth Interview Guide and observations. The two research tools strengthened the dependability and trustworthiness of the study findings, as shown from the findings and data interpretation.

\section{Data Analysis and Interpretation}

Data analysis is the process of systematically searching and arranging the interview transcripts, observation notes or other non-textual materials that the researcher accumulates to increase understanding of the phenomenon (Patton, 2002). Data was analysed from interview transcripts and texts documented by classifying, summarizing and tabulating it into identified themes. Content analysis and Narrative analysis were used for this study (Corbin, 2008). The data were coded accordingly from sources reviewed and across each case. The data was analysed thematically and the identified themes were cross-checked by the participants for validation purposes in line with (Mason, 1996).

\section{Ethical Consideration}

Consent was sought from all prospective respondents by explaining to them that the information collected was only needed for academic purposes. To assure confidentiality and privacy, pseudonyms were assigned in place of actual names as follows: T1-2020, T2-2020, T3-2020, T5-2020, T6-2020, T7-2020, T8-2020, T9-2020 and T10-2020. Respondents in the study were also assured of confidentiality for any information that would be given.

\section{STUDY FINDINGS}

The followings findings came out from the study:

$i$. Responding adequately to the prompt changes in the external environment: 
The respondents to the study, these being the teachers who put in an effort to sponsor themselves for further studies revealed that the upgrading of their qualifications has helped them to move in time, with the new technological changes in the world. All the teachers interviewed pointed out that they are now abreast with the environment of the new technologies, which has sprung up in all government institutions, including, the higher institutions of learning where they trained from. The teachers said this has made their lives easy, as they are able to easily adapt to change, since they can easily use the technological knowledge acquired during upgrading. One respondent in a verbatim stated that:

The upgrading of my qualification, which I did on selfsponsorship is one step, I will never regret doing. If you look at how dynamic the world is moving, in terms of new technologies, you will be astonished to find out that there are lots of teachers lagging behind because they never took an initiative to sponsor themselves and upgrade their qualifications. I acquired some of these new technologies when I went to upgrade my qualifications' (T1-2020).

Another teacher who was a respondent pointed out that:

I'm so happy with the initiative I undertook to further my studies on self-sponsorship because I can see the positive outcome of the decision I made on my life. I have no problems adjusting to the new technologies that have been introduced by the MoGE education, especially when it comes to analyzing exams conducted in the school (T2-2020).

\section{ii. Natural Aptitudes and inventiveness:}

In an attempt to uncover the effects that the benefits of education, derived by teachers who upgrade their qualifications on self-sponsorship, have on the lives of these teachers, findings from the respondents revealed that these teachers who upgraded their qualifications on self-sponsorship are experiencing natural aptitudes and inventiveness in their lives. This is a situation where the teachers are able to apply a special intelligence in their way of approaching issues that come their way. Out of the 10 respondents interviewed, 8 respondents stated that, after upgrading their qualifications, on self-sponsorship, from diploma to degree level, they have now become faster, better and more exhaustively in analyzing issues critically. This has made them to realize that they have developed the skill of natural aptitudes and inventiveness, because they now have skills to monitor, manage and improve situations which they encounter in life. All this is as a result of the training and education acquired during upgrading. The other 2 respondents also agreed that the upgrading of qualifications through personal efforts on self-sponsorship has effects on one's life, but they did not come out clearly to state the effects. A teacher in the following verbatim explained that:

It is not something I need to be told, but on my own, I feel it in the way I articulate on issues that, I am now more open to challenges. In approaching these challenges, I always apply skills of imaginativeness, resourcefulness and flexibility, to sort them out' (T32020).

A teacher who a respondent explained that:

I'm so happy with my achievement after taking the initiative to upgrade on self-sponsorship because the skills and knowledge I acquired during upgrading have made me to be innovative in my work. The skills and knowledge have helped me to be inventive while I execute my duties (T4-2020).

iii. New Paths towards better Health, High Income Employment Opportunities and Resonated Knowledge:

Another finding revealed that the teachers, who upgraded their qualifications on self-sponsorship, can now make better and best decisions concerning their health and that of their family members. The respondents further on went on to state that, they also have opportunities to take on new tasks at work, and this comes with more incentives. The teachers further stated that the upgrading of their qualifications on self-sponsorship has also enabled them to contribute to new and productive knowledge in their jobs and also share ideas on how to make a difference in their jobs using the skills and knowledge acquired during upgrading.

The new and productive knowledge amounts to resonated knowledge. The teachers are equipped with resonated knowledge that possess a full round deep understanding on controversial issues taking place in the society. Out of the 10 respondents interviewed, 9 agreed and attested to the mentioned effects in their lives. The other 1 respondent also agreed that the upgrading of their qualifications has had effects on his life, though they did not come out clearly on these effects. One respondent in a verbatim said that:

I lead a better health because I was empowered with a set of habits that promote a better health during my upgrading. It also hasn't been a big challenge for me to engage in extra private jobs and I now a have higher income. I have also developed awareness on how to be sustainable in social, economic and environmental issues' (T5-2020).

Another teacher revealed that:

As you can see, immediately I graduated, I was given a local appointment to work from this office that we are in. It was not difficult for me to adapt working from this guidance office where I deal with Examination of Zambia related cases because of the skills I acquired when I upgraded my qualifications. Though I paid for myself, the investment was worthy it because I'm able to handle this task without many challenges (T6-2020).

iv. Social connections: 
Regarding experiencing social connections, as a result of upgrading qualifications, 8 respondents revealed that ever since they had upgraded their qualifications from diploma to degree, they have made connections with colleagues from different backgrounds. According to the teachers, these connections have been promoting friendships, a sense of belonging, improved self-worth and confidence in their everyday endeavors. A verbatim from one of the teachers stated that:

My newly acquired associates are on a higher level academically. Through them, I have learnt so many new things from them and even the contributions I articulate are being valued and appreciated by them, it feels so great, (T7-2020).

Another teacher further stated that:

My friendship circles have completely changed from the time I graduated. This is not to say I have started looking down on those who do not have higher qualifications, but that it is to agree and reason with the colleagues who have same qualifications such as mine (T8-2020).

\section{DISCUSSION OF THE FINDINGS}

The study established that the streams of benefits derived by teachers who made personal efforts to upgrade their qualifications by paying for themselves have brought out the following effects in their lives: they can now respond adequately to the prompt changes in their external environment; their aptitudes and inventiveness have advanced; their achievement have placed them on paths towards better health, high income employment opportunities, resonated knowledge on social and economic challenges affecting them, and also social connection experience. The effects are discussed as follows:

\section{i. Adequate Response to Prompt Changes}

The current trend in the educational system of Zambia has seen higher education being ramped up dramatically over the past years with respect to the new technological changes in the world. New systems of approaching and running government institutions have been penetrated with broadband technologies and these have been helping to create a rich deliverance of working targets in institutions. The environment of new technologies that have sprung up in government institutions, the education sector inclusive, have undoubtedly reinforced and provided opportunities to the teachers so that they can meet the growing demand for interactive educational products and services. Since the Zambian government, through the MoGE has brought in technology in its curriculum, a new wave of good products needs to be created in the Zambian environment and teachers must be trained to use them in the classroom. The MoGE through one of its objectives clearly states that the teachers are an indispensable component in the development of the new technologies in the nation (EOF, 1996). However, the MoGE has not been up to date in providing opportunities of sponsoring these teachers, even when it is clear that when government invests in the education of these teachers, the better for the country. Wanchinga (2017) states that, going by the importance of teachers in the communities, those teachers who are not covered under the government's upgrading programme should not sit back, but see to it that they can upgrade their qualifications. Further, prompt responses related to inclusive education as critical parameter to quality education that require teachers' support to realize the Sustainable Development Goal particularly target number 4 cannot be emphasized (Simui, Kasonde-Ngandu, Cheyeka and Makoe, 2019; Simui, Mwewa, Chota, Kakana, Mundende, Thompson, Mwanza, Ndhlovu and Namangala, 2018; Simui, Nyaruwata and Kasonde-Ngandu, 2017; \& Simui, Mhone and Nkhuwa, 2011; and Simui, 2009).

According to the study, this is what has prompted many teachers to realize that the world around is changing every day and they need to keep abreast with the new developments, which they can better do with more education. In addition, it has been established as common knowledge among all the teachers that governments, all over the world have been placing emphasis on technological knowledge to the learners. This has been prompting the teachers to upgrade qualifications even at own cost because the teachers who have more education add value to the teaching profession. The finding is in line with the theoretical framework used in the study which stated that human development enlarges human capabilities to promote investment in the development of people through skills, work productivity and creativity (Garba, 2016). Teachers are keen to learn and improve their skills as they see the impact their learning can have on their pupils in the classroom (Bana Tandizo, 2018). The study established that one among the other established impacts that the teachers who have increased education, experience is that they acquire knowledge that empowers them to have adequate responses to the prompt changes in the external environment. Though the upgrading of qualifications on self-sponsorship makes the teachers face many hurdles, teachers who have upgraded on self-sponsorship still appreciate the results of such an effort as it makes them identify issues in the environment that require them respond to the new developments taking place in their environments.

The upgrading of qualifications on self-sponsorship has seen many of these teachers become very rich education resources, making them helpful consultants in the environment they live in since they can now disseminate knowledge to everyone to have access to the new system. Gayor (1998) confirms as she states that teachers who upgrade qualifications end up catching up with the new knowledge in the ever changing curriculum. Since the curriculum is always adjusted to suit the environment in which learners are found the opportunity to upgrade helps them to respond promptly to the changes in the external environment, then what should be done to any 
existing challenges and also insights to respond to the new development.

\section{ii. Development of Natural Aptitudes and Inventiveness.}

Another way in which teachers are impacted because they made an effort to upgrade their qualifications on selfsponsorship is that they develop natural aptitudes and inventiveness. Teachers who do not sit back and wait for government sponsorship in order to upgrade, but go on to upgrade their qualifications on self-sponsorship develop a high level of intellect that results in them being able to produce desired results in their work. Developing high levels of intellect which eventually leads to producing desired results by these teachers is what is referred to as natural aptitudes and inventiveness. Richard \& Linda (2019) state that, many highly accomplished thinkers rightly considered geniuses, have displayed that brilliance only after investing years in perfecting potential. Teachers who invest in education are considered to be geniuses who develop activeness through the knowledge acquired and this knowledge enables them to apply their imaginations needed to generate new ideas and questions. The teachers revealed in the findings of the study that they become more open to new challenges. The teachers further on went to state that, because of the new knowledge acquired after upgrading their qualifications, they have also become resourceful, imaginative and flexible when approaching issues. Natural aptitudes and inventiveness developed by the teachers who have acquired higher qualifications teach the teachers to think in a way that is unique to them. This was revealed by the teachers who were the respondents in the study to state that they have now become skillful and have developed a specific understanding of how to deal with issues. Showers \& Joyce (1980) agree with the teachers experiences as they state that, critical thinkers develop an awareness of the assumptions under which others think and act. This shows that the outcome of the developed natural aptitudes and inventiveness clearly makes the teachers who acquired more knowledge through upgrading their qualifications to become more committed in their work. The commitment can be seen through hard work, persistence perseverance traits in their work.

The knowledge and skills acquired after the upgrading of the qualifications is said to have been enabling the teachers to be on the lookout at issues from different angles and perspectives. The knowledge and skills enhancement has also empowered them with a kind of creativeness, which enables them to experiment with new ideas that they come across in their teaching. This kind of creativeness is at a level where the teachers are now able to pursue the new ideas, using the inquiry approach as they teach the learners. The respondents of the study went on to state that, natural aptitudes and inventiveness are very critical in all academic disciplines and educational activities, for every practicing teacher. They play the role of career development. Career development is the act of acquiring information and resources that enables one to plan a programme of lifelong learning related to his or her work life (Blashki, 2013).

Clearly, the findings of the study have shown that the practicing teachers who upgrade on their qualifications, advance their skills and pedagogical knowledge. The advancement of the skills and pedagogical knowledge makes the teachers to possess their natural aptitudes or high intellect levels and innovation. These qualities are required in their dynamic teaching roles. This results in them, being teachers, who can discover and analyse the world in which they live in, critically. The findings are in line with what Jostein (2015) reviewed in the literature that the theory of human capital postulates that individuals who bear the costs such as paid school fees and opportunity costs in an educational investment expect that the investment will create a future streams of benefits.

\section{iii. New Paths towards better Health, High Income Employment Opportunities and Resonated Knowledge.}

The study established that when teachers get more educated, their mental capabilities and technical skills increased. Education comes with levels. The more a teacher gets educated, the more their mental capabilities and technical capabilities. Teachers invested in education because of the expected returns or benefits. The more the investment in education through upgrading of one's qualification, the more the benefits. The benefits or returns had effects on the investors who were the teachers, in a number of ways. The study went on to reveal that the teachers who had upgraded their qualifications on self-sponsorship had earned themselves paths towards better living styles both economically and socially. According to the findings of the study, the teachers who were the respondents revealed that their health and that of their family members is well taken care of by themselves, because of the knowledge acquired during the upgrading.

The knowledge acquired during the upgrading had been serving as a pathway to a better health because of the good sets of habits they acquired that promote a better health. The habits that the teachers developed as a result of investing in education, when put into practice were noticed through the lifestyles they begin to lead. Alika et al (2014) posited that, individual abilities can be enhanced through education and training that brings about effective change in the lives of the people that have acquired more education. The findings further revealed that the teachers who upgrade their qualifications have always ended up getting high income employment. This was revealed in the findings where it was discovered that there was a strong relationship between education and income. This is in line with reviewed literature which state that the human capital theory predicts that increases in the overall levels of education can benefit individuals and society in ways that are not fully reflected in the returns (Jenkins, 2018). The implication is that when one has more education, and then there are very high chances of earning higher income. More education is attained by 
upgrading qualifications. Benjamin (2012) posits that, there is a significant and positive relationship between higher education level and income and that is higher education qualifications leads to higher income. These findings are in line with the experiences of the respondents used in this study, as it was revealed by them that they have experienced income rise as a result of upgrading.

The findings also showed that the teachers had also acknowledged that the upgrading of their qualification through their own efforts, had led them to start comprehending issues affecting them and their work at a higher level because they are now equipped with wider knowledge on social, economic and environmental challenges, leading to resonated knowledge. Resonated knowledge is the ability to think through presented issues, in a critical manner as well as objectively. In other words, the teachers who did not sit back to wait for sponsorship but instead, put in their own efforts to upgrade qualifications are now able to present strong arguments using the knowledge acquired in a more rational way. The issues of concern are mainly in line with social, economic and environmental challenges. In order to address these challenges, teachers have been applying persuasive and well-reasoned arguments that lead to conclusions based evidence. This experience is in line with what Armstrong \& Stanton (2006) revealed, that the ability to weigh alternative decisions and evaluate contradictory evidence is crucial to scholastic endeavors and adult life more generally to personal happiness, professional success, and civic engagement.

\section{iv. Social Connections}

The findings of the study further revealed that, the teachers who attained high levels of education through upgrading qualifications are experiencing social connections. The effects of the social connections in their lives are in such a way that they now feel valued because their contribution towards various issues affecting them and their society are being appreciated by their newly acquired acquaintances. Social connections have to do with friendships, a sense of belonging, improved self-worth, confidence as well as purpose. Eisenberger \& Cole (2012) defined social connections as the relationships, networks or links that people have with other people or groups, whether these be with neighbors, family, friends, sporting or social groups.

It was established from the participants of the study that social connections are very important for them, if they had to be a successful workforce. The general state of affairs depicts that, social connections can either positively or negatively affect the employees' productivity and also the general feelings of belonging. The teachers who took part in the study stated that, it had turned out for them that the social connections that they had now earned for themselves had positive effects on their lives. The teachers revealed that the knowledge acquired during the time of upgrading had made them start appreciating and understanding the importance of social connections in their careers. The revelations sit well with the theoretical framework used in the study which stated that an investment in education brings out the capacity in the investor to work and adapt to new life because education instills the correct approach towards life (Winters, 2013).

The newly acquired social connections have helped teachers become more engaged and loyal in their work. This resulted in the teachers building a strong bond that emphasizes on respect, loyalty and trust. The social connections have also helped the teachers develop a sense of cohesion in their work places, which is very important for cultivating creativity, teamwork and collaboration. The participants of the study were quick to point out, on the other hand, that social connections in places of work should not mean that the teachers have to become best friends or get along or the time, as this may end up bringing laziness in work places. The connections are purely about the teachers feeling valued and appreciated in all their contributions in the work environment. This promotes respect, trust and belonging among the teachers as team mates or workmates. Vic Health (2009) sums it all as they state, how much you earn, your social position, your level of education and your capacity to be involved in activities that help one to connect to others in the community are important factors.

\section{CONCLUSION}

This study aimed at exploring the effects of the educational investments and returns on the lives of teachers who invested in education by upgrading qualifications through selfsponsorship. The private social and economic benefits of education derived by the teachers who invested in education included higher wages, wider opportunities to acquire employment and also novelty among others. The investment in education made by teachers who upgraded their qualifications on self-sponsorship brought about a number of opportunities to them. The study showed that when teachers sacrifice and make an effort to invest in education by upgrading on self-sponsorship, the investment yields private economic returns and private social returns. The returns accrued have positive effects on the lives of the teachers. Therefore the study concluded that investing in education by upgrading qualifications on self-sponsorship, is a worthy investment for teachers who make efforts and sacrifice their resources to upgrade. The investment is worthy because it yields returns that have positive effects on lives of the teachers.

\section{RECOMMENDATIONS}

The study recommended that:

1. Teachers who fail to get sponsorship opportunities from the government can go ahead and upgrade their qualifications on self-sponsorship because the benefits of education or returns accrued after upgrading have positive effects on their lives. 
2. There is need for teachers to go ahead and upgrade qualifications on self-sponsorship so as to improve on their knowledge reservoir.

3. Teachers need to make efforts, sacrifice their resources and upgrade on self-sponsorship in order to enhance their efficiency and effectiveness, which are abreast with the technological advancements that are now widely used in all government institutions.

\section{REFERENCES}

[1]. Alika, I, J \& Stan A, Journal of Business Administration and Education 2201-2958, 5, Number 1, 2014, 55-78.

[2]. Armstrong, P. \& Stanton.K (2006), Learning to analyze and critically evaluate ideas, arguments and points of view; The Idea Center.

[3]. Benjamin. (2012). A study on the Relationship between Education level and income in the USA- Slide share.

[4]. BETUZ. (2015). The Status of Education in Zambia Report: A Focus on Quality Education. Lusaka: Institutional Suppliers Limited.

[5]. Blashki, K. (2013). Emerging Research and Trends in Interactivity and Human-Computer Interface; IGI Global.

[6]. Bergersen, A. and Muleya, G. (2019). "Zambian Civic Education Teacher Students in Norway for a Year- How DoThey Describe Their Transformative Learning?"e Sustainability 2019, 11 (24), 7143; doi: 10.3390/su11247143, pp 117 www.mdpi.com/journal/sustainability

[7]. Cathy Gaynor (1998). Directions in Development: Decentralization of Education Teacher Management; Washington, D.C. The World Bank.

[8]. Corbin, J. (2008). Basics of Qualitative Research Techniques and Procedures for Developing Grounded Theory. Thousand Oaks, SAGE Publications.

[9]. Cohen, D. \& Soto, M. (2015). Growth and human Capital: Good data, good results. Journal of Economic Growth, 1 (3), 113-207.

[10]. Garba, P. K. (2016). Human Capital formation, utilization and Development of Nigeria. Selected Papers for the 2002 Arrival Conference of the Nigeria Economic Society.( NES). Ibadan: Polygraphics Ventures Ltd.

[11]. Habanyati, H., Simui, F., Kanyamuna, V., \& Muleya, G. (2020) Lived Experiences of Multi-Banked Bank AccountHolders with a focus on Banks at Manda Hill Mall Lusaka, Zambia. Advances in Social Sciences Research Journal, 7(6) 208-223.

[12]. Jeffrey. A.F \& Todd, V.K (2000). Investment Opportunities in Education: Making a Difference: The Journal of Private Equity .3, .4 (fall 200), 38-51: Euro money, institutional investor PLC.

[13]. Jenkins, A. (2018). Who upgrade to Higher Level Qualifications in Midlife? British Journal of Educational Studies. 66 (2). 243-266.

[14]. Joyce, B.R \& Showers, B. (1980). Improving in-service training The messages of Research; Educational Leadership, 37, 5, February, 379-85.

[15]. Kristain, B. \& Erica, B. (2018). Evaluating the Return of Investment in Higher Education: AN Assessment of individualState- Level Returns; Atlanta Georgia; GEORGIA State University.

[16]. Machila,N, Sompa, M, Muleya, G and Pitsoe, V.J (2018). 'Teachers' Understanding and AttitudesTowards Inductive and Deductive Approaches to Teaching Social Sciences," Multidisciplinary Journal of Language and Social Sciences Education, (2), 120-137. 2018

[17]. Magasu, O., Muleya, G. \& Mweemba, L. (2020). Pedagogical Challenges in Teaching Civic Education in Secondary Schools in Zambia. International Journal of Science and Research (IJSR). Vol. 9, Issue 3, pp. 1483-1488. DOI: 10:21274/SR 20327121153.

[18]. Mason, J. (1996). Qualitative Research. Thousand Oaks: SAGE Publications.
[19]. Muleya, G. (2017a). 'The Conceptual Challenges in the Conceptualization of Civic Education'. In Journal ofLexicography and Terminology. Vol 1, Issue 1, pp 59-81

[20]. Muleya, G. (2017b). 'Civic education and Civics: Where do we draw the line?' In Journal of Lexicography andTerminology. Vol 1 , Issue 2, pp 125-148.

[21]. Muleya, G. (2018b). 'Civic Education Versus Citizenship Education? Where is the point of Convergence?' Journal ofLexicography and Terminology, Vol 2, Issue No. 1, pp 109-130.

[22]. Muleya, G. (2018a). Civic education in Zambia before and beyond the Golden Jubilee. In G. Masaiti (Ed.), Educationat fifty years of Independence and beyond. Lusaka: Unza Press.

[23]. Muleya, G.(2018c). Re-Examining the Concept of Civic Education. Journal of Lexicography and Terminology, Vol 2, Issue No. 2, pp 25- 42.

[24]. Muleya, G. (2019). Curriculum Policy and Practice of Civic Education in Zambia: A Reflective Perspective, In A.

[25]. Petersen et al. (eds.). The Palgrave Handbook of Citizenship and Education. https://doi/10.007/978-3-319-67905-153-1

[26]. Mupeta, S and Muleya, G. (2019). Challenges and Strategies in the Implementation of Civic Entrepreneurship in the Governance of the University of Zambia, In International Journal of Research and Innovation in Social Science (IJRISS) |Volume III, Issue VII, July 2019|ISSN 2454-6186, pp $94-100$

[27]. Mupeta, S., Muleya, G., Kanyamuna, V., \& Simui, F. (2020). Civic Entrepreneurship: The Implementation of CivicInnovations in the Governance of the University of Zambia. Advances in Social Sciences Research Journal, 7(7) 674-685.

[28]. Patton, M. Q. (2002). Evaluation Methods. Thousand Oaks, California: SAGE Publications.

[29]. Phiri, J.N. (2015). Education Public Expenditure Review in Zambia. Lusaka: Ministry of Education.

[30]. Neuman, W.L. (2007). Basics of Social Research Methods: Qualitative and Quantitative Approaches. Boston: Pearson Education.

[31]. Richard, P. \& Linda, E. (2019). The Nature and Functions of Critical and Creative thinking: Maryland Rowman \& Littlefields.

[32]. Simui, F., Kasonde Ngandu, S., Cheyeka, A.M., and Makoe, M., (2019). Lived Disablers to Academic Success of the Visually Impaired at the University of Zambia. Sub Saharan Africa. Journal of Student Affairs in Africa 7(2), 41-56. https://doi.org/10.24085/jsaa.v7i2.3824

[33]. Simui, F., Mwewa, G., Chota, A., Kakana, F., Mundende, K., Thompson, L., Mwanza, P., Ndhlovu, D., \& Namangala, B., (2018). "WhatsApp" as a Learner Support tool for distance education: Implications for Policy and Practice at University of Zambia. Zambia ICT Journal, 2, (2), 36-44, https://doi.org/10.33260/zictjournal.v2i2.55.

[34]. Simui, F., Nyaruwata, L.T. and Kasonde-Ngandu, S. (2017). ICT as an Enabler to Academic Success of Students with Visually Impaired at Sim University: Hermeneutics Approach. Zambia ICT Journal Vol. $1 . \quad$ Issue $1 . \quad$ pp 5 - 9 . http://ictjournal.icict.org.zm/index.php/zictjournal/article/view/9

[35]. Simui, F. Mhone, M., \& Nkhuwa, A., (2011). A Baseline Study on the Effectiveness of the Head Teachers' Education Leadership and Management Course on Learner Performance. Lusaka: Ministry of Education.

[36]. Simui F. (2009). Preparing Teachers for Inclusive Education: A Study of the English Approach. Paper Presented at the SANORD 2ND International Conference: Inclusive and Exclusion in Higher Education, Rhodes University, Grahmstown, South Africa, December 7 to $9,2009$.

[37]. TEVET NEWS. (2011). Technical Education, Vocational and Education, Vocational and Entrepreneurship Training Authority: Lusaka: TEVET.

[38]. United Nations (2018). Globalization and Social Development. New York: NY: United Nations.

[39]. Vic Health, (2009). Opportunities for Social Connection; A determinant of mental health and wellbeing, vichealth.vicgov.au 
[40]. Wanchinga, D. Government's stance on teacher Development; Zambia Daily Mail, 24th April, 2017, 2.

[41]. Wilson, J.P. (2012). International human resource development: Learning, education and training for individuals and organizations; Philadelphia PA: Kogan Page Limited.

[42]. Winters, J.V. (2013). Human Capital Externalities and Employment differences Across Metropolitan areas of the USA. Journal of Economic Geography. 13 (5). 799-822.
[43]. Woessman, L. (2014). The Economic Case for Education: The International Evidence. Oxford Bulletin of Economics and Statistics. 65(2).117-170.

[44]. Zambia National Union of Teachers. (2017). Report on the Status of Teachers of Teachers Upgrade in Zambia: Lusaka Institutional Suppliers Limited. 